\title{
Monoclonal antibodies in non-small-cell lung cancer: Light at the end of the tunnel
}

\author{
Fatemeh Naddaf* \\ Pharmaceutical Sciences Research Center, Shahid Beheshti University of Medical Sciences, Tehran, Iran
}

\begin{abstract}
Lung cancer is the leading cause of death and non-small cell lung cancer (NSCLC) is considered as the most common type of lung cancer. Several conventional therapies, such as surgery, radiation, and chemotherapy are used for the treatment of lung cancer. But, these therapies could have multiple undesirable side effects. Therefore, there is an urgent need for therapeutic agents to improve the clinical outcomes for cases with NSCLC. Recently, therapeutic antibodies have shown promise for NSCLC treatment. The aim of this review is to discuss FDA-approved antibodies such as durvalumab, pembrolizumab, necitumumab and nivolumab in the treatment of NSCLC as well as Onartuzumab, a monoclonal antibody against c-MET, that was discontinued due to its lack of clinical activity. Furthermore, the aim of this manuscript is to give a brief overview about NSCLC therapeutic mAbs.
\end{abstract}

\section{Introduction}

Lung cancer is considered as a heterogeneous and complex disease [1]. Non-small cell lung cancer (NSCLC), the most common type of lung cancer, accounts for approximately 85 percent of all lung cancers and is classified as nonsquamous carcinoma and squamous NSCLC $[2,3]$. The primary treatment for patients with stage I, II, or IIIA NSCLC could be surgery. But, long-term survival of NSCLC cases after surgery alone might be largely unsatisfactory [4]. Though patients who receive adjuvant chemotherapy after complete resection of localized NSCLC could have an absolute survival advantage of about $5 \%$ at 5 years, there is still a relatively high risk of relapse even for early-stage NSCLC cases [5]. Furthermore, it has been indicated that third-generation chemotherapy regimens in NSCLC cases who have a good performance status could moderately improve survival at one and two years [6,7]. It has been shown that immunotherapy with monoclonal antibodies including nivolumab and pembrolizumab has improved the survival of cases with metastatic NSCLC [8]. Since many monoclonal antibodies against programmed cell death (PD-1) have been introduced to enhance anticancer immune responses and cause tumor cell death, targeting PD-1 pathway is considered as a new anticancer strategy [9]. It has been reported that response rates in cases with pretreated, advanced NSCLC were higher and more durable with PD-1 blockade therapy in comparison with chemotherapy. Thus, PD-1 inhibitors including nivolumab and pembrolizumab were approved for squamous and nonsquamous lung cancer in the pretreated patients [10]. Pembrolizumab could improve survival as first- and second-line therapy compared to chemotherapy in cases with PD-L1 expressing advanced NSCLC [11]. Moreover, blockade of the epidermal growth factor receptor (EGFR) by monoclonal antibodies can improve outcome in cases with NSCLC [12]. Immune checkpoint inhibitors including nivolumab, pembrolizumab and durvalumab are at the forefront of immunotherapy [13]. Till now, the efficacy and toxicity of immune checkpoint inhibitors in elderly patients is unclear since related studies involved a low number of elderly cases [14]. At present, four therapeutic monoclonal antibodies have been approved for the treatment of non- small-cell lung cancer and many monoclonal antibodies are currently being tested in clinical trials (Table 1) (Figure 1).

\section{Durvalumab}

Durvalumab (MEDI4736), a high-affinity human IgG1 monoclonal antibody, was approved for the treatment of non-small cell lung cancer (NSCLC). It could bind to both programmed death protein 1 (PD-1) and CD80. As well as, programmed cell death ligand 1 (PD-L1) was blocked [15]. It has been indicated that durvalumab had encouraging antitumor activity, by allowing $\mathrm{T}$ cells to recognize and induce tumor cell death. Both chemotherapy and radiotherapy could up-regulate PD-L1 expression in tumor cells, which can be a predictive factor for a response to durvalumab. Thus, it has been suggested that durvalumab could be beneficial after chemoradiotherapy [16]. Currently, durvalumab is in many clinical trials alone or in combination with other agents, such as anti-CTLA-4 and anti-PD-1, as well as IDO, MEK, BRAF, and EGFR inhibitors [17]. The combination of both durvalumab and tremelimumab potentiates their antitumor activity in patients with advanced NSCLC, regardless of PD-L1 tumor status [18]. Till now, no immunogenicity that impacts pharmacokinetics/ pharmacodynamics of durvalumab has been observed at the $10 \mathrm{mg} / \mathrm{kg}$ (every 2 weeks) selected dose [19].

\section{Pembrolizumab}

Pembrolizumab (Keytruda (")) is a humanized monoclonal antibody that was approved on October 2, 2015 for the treatment of cases with

*Correspondence to: Fatemeh Naddafi, Pharmaceutical Sciences Research Center, Shahid Beheshti University of Medical Sciences, Tehran, Iran, Tel: 982188209627; Fax: 982188209627; E-mail: fatemeh.naddafi@yahoo.com, fatemeh.naddafi@sbmu.ac.ir

Key words: non-small cell lung cancer, therapeutic antibodies, cancer, approved drugs, FDA

Received: April 17, 2019; Accepted: May 13, 2019; Published: May 16, 2019 


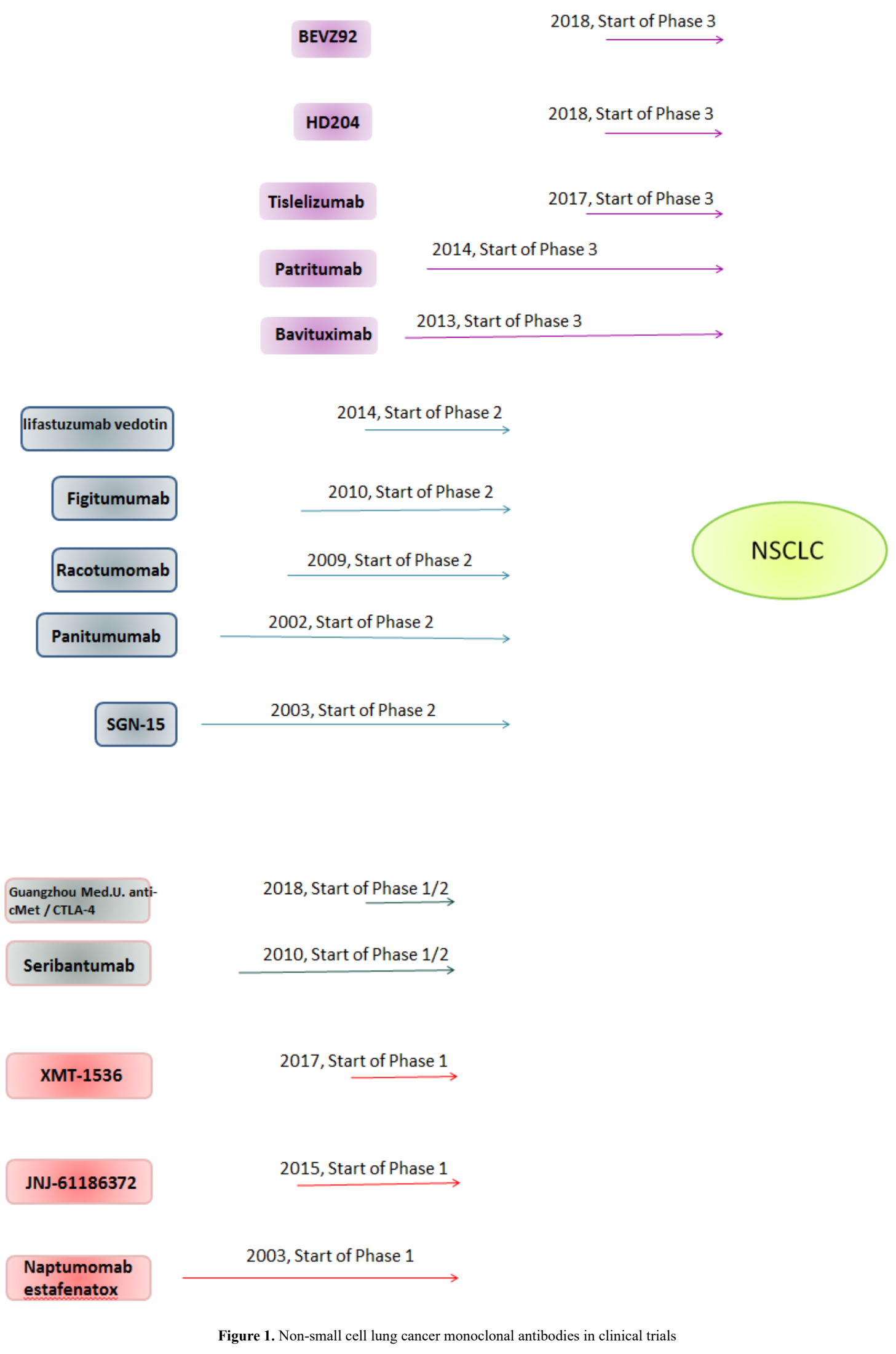


Table 1. A brief overview of non-small cell lung cancer (NSCLC) antibodies. Monoclonal antibodies are in clinical trials for treatment of NSCLC and various malignancies

\begin{tabular}{|c|c|c|c|c|c|c|}
\hline Antibody & Internal name & Antigen & Company & Phase & Condition & Antibody type \\
\hline BEVZ92 & MB02 & $\begin{array}{l}\text { Vascular endothelial } \\
\text { growth factor A }\end{array}$ & mAbxience S.A. & $\begin{array}{l}\text { 2014, Start of Phase } 1 \\
\text { 2018, Start of Phase } 3\end{array}$ & $\begin{array}{c}\text { Cancer } \\
\text { Lung cancer (non-small } \\
\text { cell) }\end{array}$ & Antibody \\
\hline $\begin{array}{c}\text { Guangzhou Anjie Biomed. } \\
\text { Tech. anti-Muc1 CAR }\end{array}$ & $\begin{array}{l}\text { Guangzhou Anjie } \\
\text { Biomed.Tech. anti- } \\
\text { Mucl CAR }\end{array}$ & Mucin 1 & $\begin{array}{c}\text { Guangzhou Anjie } \\
\text { Biomedical Technology } \\
\text { Co.Ltd. }\end{array}$ & 2018, Start of Phase 1/2 & $\begin{array}{c}\text { Lung cancer (non-small } \\
\text { cell) }\end{array}$ & Chimeric antigen receptor \\
\hline HD204 & HD204 & $\begin{array}{l}\text { Vascular endothelial } \\
\text { growth factor A }\end{array}$ & $\begin{array}{l}\text { Prestige BioPharma } \\
\text { Pte Ltd }\end{array}$ & 2018, Start of Phase 3 & $\begin{array}{l}\text { Lung cancer (non-small } \\
\text { cell) }\end{array}$ & Antibody \\
\hline JNJ-61186372 & EM1-mAb & $\begin{array}{l}\text { cMet Receptor, } \\
\text { Epidermal growth factor } \\
\text { receptor }\end{array}$ & $\begin{array}{c}\text { Genmab A/S, Janssen } \\
\text { Biotech Inc }\end{array}$ & 2015, Start of Phase 1 & $\begin{array}{l}\text { Lung cancer (non-small } \\
\text { cell) }\end{array}$ & Bispecific antibody \\
\hline SGN-15 & $\begin{array}{c}\text { SGN-15, BMS- } \\
\text { 182248, BR96-DOX }\end{array}$ & Lewis $\mathrm{y} / \mathrm{b}$ antigen & $\begin{array}{l}\text { Bristol-Myers Squibb, } \\
\text { Seattle Genetics }\end{array}$ & 2003, Start of Phase 2 & $\begin{array}{l}\text { Lung cancer (non-small } \\
\text { cell) }\end{array}$ & $\begin{array}{l}\text { Chimeric human/mouse, } \\
\text { Antibody drug conjugate }\end{array}$ \\
\hline XMT-1536 & $\begin{array}{l}\text { XMT-1535, XMT- } \\
1536\end{array}$ & $\mathrm{NaPi} 2 \mathrm{~b}$ & Mersana Therapeutics & 2017, Start of Phase 1 & $\begin{array}{c}\text { Lung cancer (non-small } \\
\text { cell) }\end{array}$ & Antibody drug conjugate \\
\hline Bavituximab & $\operatorname{ch} 3 \mathrm{G} 4$ & $\begin{array}{l}\text { Phosphatidyl } \\
\text { serine }\end{array}$ & $\begin{array}{c}\text { Peregrine } \\
\text { Pharmaceuticals, Inc. }\end{array}$ & $\begin{array}{l}\text { 2013, Start of Phase } 3 \\
\text { 2008, Start of Phase } 2 \\
\text { 2005, Start of Phase } 1\end{array}$ & $\begin{array}{c}\text { Lung cancer (non-small } \\
\text { cell) } \\
\text { Breast cancer } \\
\text { Solid tumors }\end{array}$ & $\begin{array}{l}\text { Chimeric human/mouse } \\
\text { Antibody }\end{array}$ \\
\hline Figitumumab & $\begin{array}{l}\mathrm{CP}-751871, \mathrm{CP}- \\
751,871\end{array}$ & $\begin{array}{l}\text { Insulin-like Growth } \\
\text { Factor } 1 \text { Receptor }\end{array}$ & $\begin{array}{c}\text { Amgen, } \\
\text { Pfizer, Schering-Plough }\end{array}$ & $\begin{array}{l}\text { 2010, Start of Phase } 2 \\
\text { 2007, Start of Phase } 1 \\
\text { 2003, Start of Phase } 1\end{array}$ & $\begin{array}{c}\text { Lung cancer (non-small } \\
\text { cell) } \\
\text { Breast cancer } \\
\text { Multiple myeloma }\end{array}$ & $\begin{array}{l}\text { Human - from transgenic } \\
\text { mouse Antibody }\end{array}$ \\
\hline lifastuzumab vedotin & $\begin{array}{c}\text { RG7599, } \\
\text { DNIB0600A }\end{array}$ & $\mathrm{NaPi} 2 \mathrm{~b}$ & $\begin{array}{l}\text { Genentech Inc. Seattle } \\
\text { Genetics }\end{array}$ & 2014, Start of Phase 2 & $\begin{array}{l}\text { Lung cancer (non-small } \\
\text { cell) }\end{array}$ & $\begin{array}{l}\text { Human, Antibody drug } \\
\text { conjugate }\end{array}$ \\
\hline Naptumomab estafenatox & ABR-217620 & $\begin{array}{l}\text { Trophoblast } \\
\text { glycoprotein }\end{array}$ & Active Biotech Research & $\begin{array}{l}\text { 2007, Start of Phase } 2 / 3 \\
\text { 2003, Start of Phase } 1\end{array}$ & $\begin{array}{l}\text { Renal cell carcinoma } \\
\text { Lung cancer (non-small } \\
\text { cell) }\end{array}$ & Mouse, Other \\
\hline Panitumumab & $\begin{array}{l}\text { ABX-EGF, clone } \\
\text { E7.6.3, Pmab, } 139\end{array}$ & $\begin{array}{l}\text { Epidermal growth factor } \\
\text { receptor }\end{array}$ & $\begin{array}{l}\text { Abgenix (Amgen), } \\
\text { Amgen }\end{array}$ & $\begin{array}{c}\text { 2006, Approved } \\
\text { 2002, Start of Phase } 2 \\
\text { 2000, Start of Phase } 1\end{array}$ & $\begin{array}{c}\text { Colorectal cancer } \\
\text { Lung cancer (non-small } \\
\text { cell) } \\
\text { Head and neck cancer }\end{array}$ & $\begin{array}{l}\text { Human - from transgenic } \\
\text { mouse Antibody }\end{array}$ \\
\hline Patritumab & AMG 888, U3-1287 & $\begin{array}{l}\text { Receptor tyrosine- } \\
\text { protein kinase erbB-3 }\end{array}$ & $\begin{array}{c}\text { Amgen, } \\
\text { Daiichi Sankyo, Inc, } \\
\text { U3 Pharma GmbH }\end{array}$ & $\begin{array}{l}\text { 2014, Start of Phase } 3 \\
\text { 2010, Start of Phase } 2\end{array}$ & $\begin{array}{c}\text { Lung cancer (non-small } \\
\text { cell) } \\
\text { Cancer }\end{array}$ & $\begin{array}{l}\text { Human - from transgenic } \\
\text { mouse Antibody }\end{array}$ \\
\hline Racotumomab & $1 \mathrm{E} 10$ & Ganglioside GM3 & Recombio & 2009, Start of Phase 2 & $\begin{array}{l}\text { Lung cancer (non-small } \\
\text { cell) }\end{array}$ & Mouse Antibody \\
\hline Seribantumab & $\begin{array}{l}\text { MM-121, } \\
\text { SAR256212 }\end{array}$ & $\begin{array}{l}\text { Receptor tyrosine- } \\
\text { protein kinase erbB-3 }\end{array}$ & $\begin{array}{c}\text { Merrimack } \\
\text { Pharmaceuticals Inc, } \\
\text { Sanofi-aventis }\end{array}$ & $\begin{array}{l}\text { 2011, Start of Phase } 2 \\
\text { 2010, Start of Phase } 1 / 2\end{array}$ & $\begin{array}{c}\text { Breast cancer } \\
\text { Lung cancer (non-small } \\
\text { cell) }\end{array}$ & $\begin{array}{c}\text { Human - from phage display } \\
\text { Antibody }\end{array}$ \\
\hline Tislelizumab & BGB-A317 & $\begin{array}{l}\text { Programmed Cell } \\
\text { Death } 1\end{array}$ & $\begin{array}{c}\text { BeiGene Ltd, } \\
\text { Celgene Corporation }\end{array}$ & $\begin{array}{l}\text { 2017, Start of Phase } 3 \\
\text { 2017, Start of Phase } 1 / 2 \\
\text { 2015, Start of Phase } 1\end{array}$ & $\begin{array}{c}\text { Lung cancer (non-small } \\
\text { cell) } \\
\text { Solid tumors } \\
\text { Cancer }\end{array}$ & $\begin{array}{l}\text { Humanized undefined source } \\
\text { Antibody }\end{array}$ \\
\hline
\end{tabular}

metastatic NSCLC whose tumors express PD-L1 as well as patients who have disease progression on or after platinum- based chemotherapy or targeted therapy against anaplastic lymphoma kinase (ALK) or epidermal growth factor receptor (EGFR) [20,21]. Pembrolizumab showed antitumor activity in cases with advanced NSCLC. It has been indicated that PD-L1 expression in at least 50 percent of tumor cells could be related to improved efficacy of pembrolizumab [22]. It has been demonstrated that a combination of pembrolizumab, carboplatin, and pemetrexed can be an effective and tolerable first-line treatment option for advanced non-squamous NSCLC [23]. In another study, the addition of pembrolizumab to standard chemotherapy of pemetrexed and a platinum containing drug could result in longer overall survival (OS) and progression-free survival (PFS) than chemotherapy alone in cases with previously untreated metastatic non-squamous NSCLC without EGFR/ALK mutations [24].

\section{Necitumumab}

Necitumumab, a fully human IgG1 monoclonal antibody, was approved in 2015 for the treatment of NSCLC [25]. It could target and bind to the EGFR to prevent the interactions between the receptor and its ligands [26]. The most common necitumumab treatment adverse events were infusion reactions, hypomagnesemia, diarrhea, and dermatological toxicities [26]. Though it has been considered as a safe and effective drug for squamous NSCLC, the clinical utility of necitumumab could be limited due to the high cost of the drug and toxic effects occurred when combined with both cisplatin and gemcitabine. Moreover, many clinical studies are ongoing to investigate the utilization of necitumumab [26]. It is indicated that both necitumumab and cetuximab are internalized to a low-pH compartment more quickly than panitumumab in NSCLC cells [27]. In NSCLC cell lines such as HCC827, NCI-H1650 and EKVX, both necitumumab and cetuximab 
could induce more rapid internalization and degradation of epidermal growth factor receptor (EGFR) in comparison with that reported with panitumumab [28]. Moreover, it has been reported that necitumumab may induce ADCC against non-small cell lung cancer cell lines, and the intensity of ADCC was correlated with the level of EGFR expression on the cell surface [28]. It has been demonstrated that combination of necitumumab and standard chemotherapy (cisplatin+gemcitabine), can increase overall survival in chemo-nai"ve cases with metastatic confirmed squamous cell histology [29].

\section{Nivolumab}

Nivolumab is a fully human IgG4 programmed death 1 (PD-1) immune-checkpoint-inhibitor antibody which is approved in NSCLC in 2015 [25,30]. It can disrupt the negative signal that mediates T-cell activation and proliferation via binding to PD-1 on activated immune cells in order to selectively block the interaction of the PD-1 receptor with its two programmed death ligands (PD-L1 and PD-L2) [30]. Nivolumab was active in advanced NSCLC in first- and second-line settings. Furthermore, it was superior to docetaxel with respect to overall response rate (ORR), progression-free survival (PFS) and overall survival (OS) in squamous cell and nonsquamous cell NSCLC [31]. Tumor PD-L1 overexpression has been related to higher ORR, but nivolumab could be active among cases with PD-L1 expression less than $1 \%$ and nonsquamous histology [31]. It has been indicated that among cases with advanced nonsquamous NSCLC who had progressed during or after platinum-based chemotherapy, OS was reported to be longer with nivolumab than with docetaxel [32]. Nivolumab monotherapy has been shown to produce durable responses and encouraging survival rates in cases with heavily pretreated NSCLC. Moreover, randomized clinical studies with nivolumab in advanced NSCLC are ongoing [33]. It has been shown that the combination of both PD-1/PD-L1 and CTLA4 antibodies can increase toxicity more than PD-1/PD-L1 blockade alone in cases with advanced NSCLC, but further investigation is needed [34]. Recently, the PD-L1 immunohistochemistry (IHC) assay is used in late-stage nivolumab clinical trials of multiple indications such as NSCLC [35]. The clinical validation of the assay and its utility in identifying cases for nivolumab treatment have been indicated in 2 phase III studies in previously treated non-small cell lung cancer with distinct histology. Moreover, the clinical utility of PD-L1 IHC assay is being further investigated in NSCLC clinical studies in the first-line setting [35]. It has been shown that the combination of nivolumab and platinum-based doublet chemotherapy (PT-DC) could provide benefit beyond single-modality chemotherapy. Thus, this can be a treatment option for cases with rapidly progressing disease or patients whose tumors do not express PD-L1 [36].

\section{Onartuzumab}

Onartuzumab is derived from the 5D5 antibody previously indicated to bind the MET Sema domain [37]. Onartuzumab entered phase 3 in 2012 in non-small cell lung cancer but discontinued in 2014 [25]. Onartuzumab can block hepatocyte growth factor (HGF) $\alpha$-chain binding to the receptor tyrosine kinase MET. Thus, targeting MET could be a promising therapeutic strategy [37]. After promising results obtained from both preclinical and phase I studies, a randomized phase II trial was designed in advanced NSCLC in $2^{\text {nd }}$ or $3^{\text {rd }}$ line treatment. 128 cases have been randomized between an association of erlotinib plus placebo and erlotinib plus Onartuzumab ( 15 mg per kg IV every 3 weeks) until progression or toxicity [38]. It has been indicated that cases with overexpression of Met in immunohistochemistry had a progressionfree survival and an overall survival two-fold and three-fold longer, respectively, than cases with negative immunohistochemistry score. Moreover, it has been reported that the erlotinib plus onartuzumab can have a worse effect on both SSP and OS than the control arm in cases with negative immunohistochemistry [38].

\section{Conclusion}

Most lung cancer cases still die from their disease. Thus, there is an urgent need for more effective therapies. With 15 monoclonal antibodies in clinical trials as well as four FDA-approved drugs, it is obvious that this is becoming an attractive approach for NSCLC treatment. It has been indicated that monoclonal antibodies against vascular endothelial growth factor receptor (VEGFR) or epidermal growth factor receptor (EGFR) might enhance the survival compared to chemotherapy alone. PD-1 inhibitors including nivolumab and pembrolizumab had been widely used in advanced cancers. Furthermore, PD-L1 expression in at least 50 percent of cancer cells can be related to improved efficacy of pembrolizumab. In previously treated cases with advanced, refractory, squamous NSCLC, nivolumab has a favorable safety profile and might restore antitumor immunity. Moreover, both PD-1 and PD-L1 antibodies, with a good safety profile and manageable side effects, show durable responses in non-small cell lung cancer. Thus, it seems that monoclonal antibodies can improve the outcome including survival in NSCLC patients.

\section{Conflict of interests}

The author declared no conflict of interests.

\section{References}

1. Hensing T, Chawla A, Batra R, Salgia R (2014) A personalized treatment for lung cancer: molecular pathways, targeted therapies, and genomic characterization. Systems Analysis of Human Multigene Disorders: Springer 2014: 85-117.

2. Piperdi B, Merla A, Perez-Soler R (2014) Targeting angiogenesis in squamous nonsmall cell lung cancer. Drugs 74: 403-413. [Crossref]

3. Socinski MA, Obasaju C, Gandara D, Hirsch FR, Bonomi P, et al. (2016) Clinicopathologic features of advanced squamous NSCLC. Journal of Thoracic Oncology 11: 1411-1422.

4. Scagliotti GV, Fossati R, Torri V, Crino L, Giaccone G, et al. (2003) Randomized study of adjuvant chemotherapy for completely resected stage I, II, or IIIA non-small-cell lung cancer. Journal of the National Cancer Institute 95: 1453-1461.

5. Mascaux C, Shepherd FA (2013) Adjuvant chemotherapy after pulmonary resection for lung cancer. Thoracic Surgery Clinics 23: 401-410.

6. Schiller JH, Harrington D, Belani CP, Langer C, Sandler A, et al. (2002) Comparison of four chemotherapy regimens for advanced non-small-cell lung cancer. New England Journal of Medicine 346: 92-98.

7. Naddafi F, Davami F (2015) Anti-CD19 monoclonal antibodies: a new approach to lymphoma therapy. International Journal of Molecular and Cellular Medicine 4: 143.

8. Bassanelli M, Sioletic S, Martini M, Giacinti S, Viterbo A, et al. (2018) Heterogeneity of PD-L1 Expression and Relationship with Biology of NSCLC. Anticancer Res 38: 3789-3796. [Crossref]

9. Sui X, Ma J, Han W, Wang X, Fang Y, et al. (2015) The anticancer immune response of anti-PD-1/PD-L1 and the genetic determinants of response to anti-PD-1/PD-L1 antibodies in cancer patients. Oncotarget 6: 19393.

10. Somasundaram A, Burns TF (2017) The next generation of immunotherapy: Keeping lung cancer in check. J Hematol Oncol 10: 87. [Crossref]

11. Hui R, Garon EB, Goldman JW, Leighl NB, Hellmann MD, et al. (2017) Pembrolizumab as first-line therapy for patients with PD-L1-positive advanced non-small cell lung cancer: a phase 1 trial. Ann Oncol 28: 874-881. [Crossref]

12. Pirker R, Filipits M (2011) Monoclonal antibodies against EGFR in non-small cell lung cancer. Critical Reviews in Oncology/Hematology 80: 1-9.

13. Reck M, Heigener D, Reinmuth N (2016) Immunotherapy for small-cell lung cancer Emerging evidence. Future Oncol 12: 931-943. [Crossref] 
14. Sgambato A, Casaluce F, Gridelli C (2017) The role of checkpoint inhibitors immunotherapy in advanced non-small cell lung cancer in the elderly. Expert Opinion on Biological Therapy 17: 565-571.

15. Mezquita L, Planchard D (2018) Durvalumab in non-small-cell lung cancer patients: Current developments. Future Oncology 14: 205-222.

16. Antonia SJ, Villegas A, Daniel D, Vicente D, Murakami S, et al. (2017) Durvalumab after chemoradiotherapy in stage III non-small-cell lung cancer. New England Journal of Medicine 377: 1919-1929.

17. Stewart R, Morrow M, Hammond S, Mulgrew K, Marcus D, et al. (2015) Identification and characterization of MEDI4736, an antagonistic anti-PD-L1 monoclonal antibody. Cancer Immunol Res 3: 1052-1062. [Crossref]

18. Planchard D, Yokoi T, McCleod MJ, Fischer JR, Kim YC, et al. (2016) A phase III study of durvalumab (MEDI4736) with or without tremelimumab for previously treated patients with advanced NSCLC: rationale and protocol design of the ARCTIC study. Clinical Lung Cancer 17: 232-236.

19. Ibrahim R, Stewart R, Shalabi A (2015) PD-L1 blockade for cancer treatment: MEDI4736. Semin Oncol 42: 474-483. [Crossref]

20. Sul J, Blumenthal GM, Jiang X, He K, Keegan P, et al. (2016) FDA approval summary: pembrolizumab for the treatment of patients with metastatic non-small cell lung cancer whose tumors express programmed death-ligand 1. The Oncologist 21: 643-650.

21. Deeks ED (2016) Pembrolizumab: A Review in Advanced Melanoma. Drugs 76: 375386. [Crossref]

22. Garon EB1, Rizvi NA, Hui R, Leighl N, Balmanoukian AS, et al. (2015) Pembrolizumab for the treatment of non-small-cell lung cancer. $N$ Engl $J$ Med 372: 2018-2028. [Crossref]

23. Langer CJ, Gadgeel SM, Borghaei H, Papadimitrakopoulou VA, Patnaik A, et al. (2016) Carboplatin and pemetrexed with or without pembrolizumab for advanced, nonsquamous non-small-cell lung cancer: a randomised, phase 2 cohort of the open-label KEYNOTE-021 study. The Lancet Oncology 17: 1497-1508.

24. Gandhi L, Rodríguez-Abreu D, Gadgeel S, Esteban E, Felip E, et al. (2018) Pembrolizumab plus chemotherapy in metastatic non-small-cell lung cancer. $N$ Engl $J$ Med 378: 2078-2092. [Crossref]

25. Siqueira LM, Committee on substance use and prevention (2017) Nicotine and Tobacco as Substances of Abuse in Children and Adolescents. Pediatrics 139. [Crossref]

26. Brinkmeyer JK, Moore DC (2016) Necitumumab for the treatment of squamous cell non-small cell lung cancer. Journal of Oncology Pharmacy Practice.
27. Topper M, Tonra J, Pytowski B, Eastman S, Editors (2011) Differentiation between the EGFR antibodies necitumumab, cetuximab, and panitumumab: Antibody internalization and EGFR degradation. ASCO Annual Meeting Proceedings.

28. Greillier L, Tomasini P, Barlesi F (2015) Necitumumab for non-small cell lung cancer Expert Opin Biol Ther 15: 1231-1239. [Crossref]

29. Sacco PC, Maione P, Rossi A, Sgambato A, Casaluce F, et al. (2015) Necitumumab for the treatment of stage IV metastatic squamous non-small-cell lung cancer. Expert Review of Respiratory Medicine 9: 245-254.

30. Li Y, Fu T, Liu T, Guo H, Guo Q, et al. (2016) Characterization of alanine to valine sequence variants in the $\mathrm{Fc}$ region of nivolumab biosimilar produced in Chinese hamster ovary cells. mAbs.

31. Aguiar Jr PN, Santoro IL, Tadokoro H, de Lima Lopes G, Filardi BA, et al. (2016) A pooled analysis of nivolumab for the treatment of advanced non-small-cell lung cancer and the role of PD-L1 as a predictive biomarker.

32. Borghaei H, Paz-Ares L, Horn L, Spigel DR, Steins M, et al. (2015) Nivolumab versu docetaxel in advanced nonsquamous non-small-cell lung cancer. New England Journal of Medicine 373: 1627-1639.

33. Gettinger SN, Horn L, Gandhi L, Spigel DR, Antonia SJ, et al. (2015) Overall survival and long-term safety of nivolumab (anti-programmed death 1 antibody, BMS-936558, ONO-4538) in patients with previously treated advanced non-small-cell lung cancer. Journal of Clinical Oncology 33: 2004-2012.

34. O’kane GM, Labbé C, Doherty MK, Young K, Albaba H, et al. (2016) Monitoring and management of immune-related adverse events associated with programmed cell death protein-1 axis inhibitors in lung cancer. The Oncologist 2016: 0164.

35. Phillips T, Simmons P, Inzunza HD, Cogswell J, Novotny Jr J, et al. (2015) Development of an automated PD-L1 immunohistochemistry (IHC) assay for non-small cell lung cancer. Applied Immunohistochemistry and Molecular Morphology 23: 541.

36. Rizvi NA, Hellmann MD, Brahmer JR, Juergens RA, Borghaei H, et al. (2016) Nivolumab in combination with platinum-based doublet chemotherapy for first-line treatment of advanced non-small-cell lung cancer. Journal of Clinical Oncology 34 2969-2979.

37. Merchant M, Ma X, Maun HR, Zheng Z, Peng J, et al. (2013) Monovalent antibody design and mechanism of action of onartuzumab, a MET antagonist with anti-tumor activity as a therapeutic agent. Proceedings of the National Academy of Sciences 110 E2987-E2996.

38. Giroux LÉ (2013) A new drug in thoracic oncology: MetMab (onartuzumab). Revue de Pneumologie Clinique 69: 152-158.

Copyright: $\left({ }_{2} 2019\right.$ Naddafi F. This is an open-access article distributed under the terms of the Creative Commons Attribution License, which permits unrestricted use, distribution, and reproduction in any medium, provided the original author and source are credited. 